\title{
Corona Mortis: anatomical and surgical description on 60 cadaveric hemipelvises
}

\section{Corona Mortis: descrição anatômica e cirúrgica em 60 hemipelvis cadavéricas}

\author{
Túlo Fabiano de Oliveira Leitei; Lucas Alves Sarmento Pires²; Kiyoshi Goke³; Júlio Guilherme Silva4; Carlos Alberto Araujo Chagas².
}

\begin{abstract}
A B S T R A C T
Objective: to report the prevalence of arterial corona mortis and to describe its surgical and clinical applicabilities. Methods: We dissected 60 hemipelvises (50 men and 10 women) fixed in a 10\% formalin solution for the purpose of gathering information on corona mortis. We measured the caliber and length of the obturator artery and its anastomotic branch with the aid of a digital caliper and submitted the data to statistical analyzes and comparisons with the GraphPad Prism 6 software. Results: arterial corona mortis was present in $45 \%$ of the studied sample. The most common origin of the obturator artery was the internal iliac artery; however, there was one exceptional case in which it originated from the femoral artery. The caliber of the anastomotic branch was on average $2.7 \mathrm{~mm}$, whereas the caliber of the obturator artery was $2.6 \mathrm{~mm}$. Conclusion: the vascular connections between the obturator, internal iliac, external iliac and inferior epigastric arterial systems are relatively common over the upper pubic branch. The diameter and a trajectory of the anastomotic artery may vary. Thus, iatrogenic lesions and pelvic and acetabular fractures can result in severe bleeding that puts the patient's life at risk.
\end{abstract}

Keywords: Corona Mortis. Anatomic Variation. Anatomy. General Surgery.

\section{INTRODUCTION}

$\mathrm{T}$ he obturator artery $(\mathrm{OA})$ has a very variable origin, usually originating from the anterior wall of the internal iliac artery (IIA). It runs anteriorly and inferiorly on the pelvic wall below the obturator nerve (ON), perforating the obturator fascia and reaching the obturator foramen $(\mathrm{OF})^{1-3}$. In its trajectory the OA distributes several collateral branches: two muscular branches (for the iliac and internal obturator muscles), a pubic branch (which runs on the posterior surface of the pubis body to anastomose with the ipsilateral branch), a bladder branch (to the posterior face of the urinary bladder) and an anastomotic branch ${ }^{1,2}$. This latter deserves special attention due to its trajectory, as it crosses the upper branch of the pubis (UBP) perpendicularly and anastomoses with the inferior epigastric artery (IEA) $)^{1,2}$. After exiting the pelvis, the $O A$ is divided into two terminal branches, an internal branch, with path at the inner border of the OF giving branches to the external obturator, pectin, and gracile muscles, and an external branch, which runs at the OF outer border to form the cruciform anastomosis $^{1}$.

The IEA, on the other hand, is a branch of the external iliac artery (IEA). Stemming a few millimeters above the inguinal ligament (LI), it runs horizontally and superiorly to the transverse fascia and runs anteriorly towards the arcuate line, between the rectus abdominis muscle and a posterior layer of its sheath. The IEA then anastomoses with an upper epigastric artery, a branch of the internal thoracic artery. During its trajectory, the IEA gives a branch to the spermatic cord, a suprapubic branch and an anastomotic branch (for the OA) ${ }^{1,2,4}$.

Corona mortis (CM), or death crown, is defined as an arterial or venous connection between the anastomotic branches of the obturator artery and the inferior epigastric artery over the superior branch of the pubis ${ }^{5-9}$. This anatomical variant is of clinical and surgical interest, as it is susceptible to iatrogenic lesions during hernia repairs, gynecological and orthopedic procedures, and may also be damaged in fractures of the pubis or acetabulum. The literature also reports the

1 - Medical School, University of São Paulo, Institute of Radiology, São Paulo, SP, Brazil. 2 - Fluminense Federal University, Department of Morphology, Niterói, RJ, Brazil. 3 - Estácio de Sá University, Department of Anatomy, Rio de Janeiro, RJ, Brazil. 4 - Federal University of Rio de Janeiro, Department of Physiotherapy, Rio de Janeiro, RJ, Brazil. 
difficulty in performing $\mathrm{CM}$ hemostasis and the fact that this anatomical variation determines collateral circulation between EIA and the IIA $\mathrm{A}^{5-10}$.

This work aims to address the surgical and anatomical aspects of this arterial connection in $60 \mathrm{ca}$ daveric hemipelvis.

\section{METHODS}

We dissected 60 hemipelvises of adult corpses (50 men and 10 women) fixed in 10\% formalin solution to analyze the vascular pattern of the pelvic region, specifically the origins and anastomoses of the OA. Among the pelvis dissected, 32 were left and 28 , right. The cadavers used in this study belonged to the Anatomy Laboratory of the Gama Filho University.

After the dissection and analysis of the OA origin, we measured its trajectory (form origin to OF) and its caliber (transverse diameter) with the aid of a digital caliper. If the anastomotic branch of OA was present, we also evaluated this vessel's length, caliber and distance from the upper branch of the pubis to the pubic symphysis. We performed the statistical analysis with the GraphPad Prism 6 software. We report morphometric data as mean \pm standard deviation (SD). We compared the length and caliber of the anastomotic branch of both genders and sides using the Mann-Whitney- $U$ test, considering a $p$-value $<0.05$ as significant).

This work followed the norms of the $1995 \mathrm{Hel}-$ sinki Declaration (revised in Edinburgh, 2000).

\section{RESULTS}

The most common origin for OA was the IIA $(45 \%)$ (Figure 1), followed by a common trunk with IEA from the EIA (36.68\%) (Figure 2). There was one case where the OA originated from the femoral artery $(1.66 \%)$. The percentage of all origins can be verified in table 1.

Of the 60 hemipelvises, 27 (45\%) had arterial CM: 21 were men $(77.77 \%)$ and six were women (22.23\%) (Table 2). The Mann-Whitney $U$ test did not reveal a statistically significant difference of the length and caliber of the anastomotic branch between genders or sides ( $p>0.05)$.

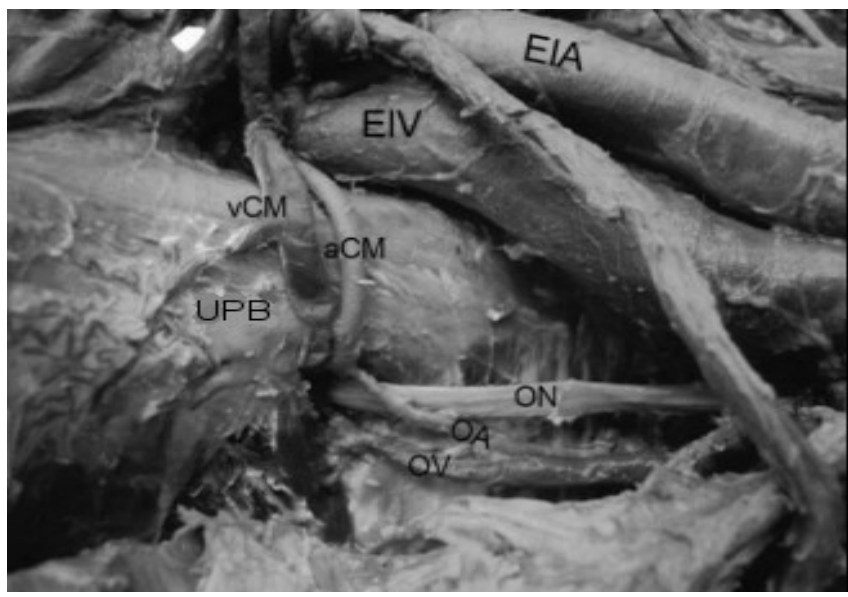

Figure 1. Dissection of a right hemipelvis. Anterior view. The Corona Mortis can be seen above the upper branch of the pubis.

External iliac artery (EIA), external iliac vein (EIV), venous Corona Mortis (VCM), arterial Coronal Mortis (aCM), upper pubic branch (UPB), obturator nerve (ON), obturator artery $(O A)$, obturator vein $(\mathrm{OV})$.

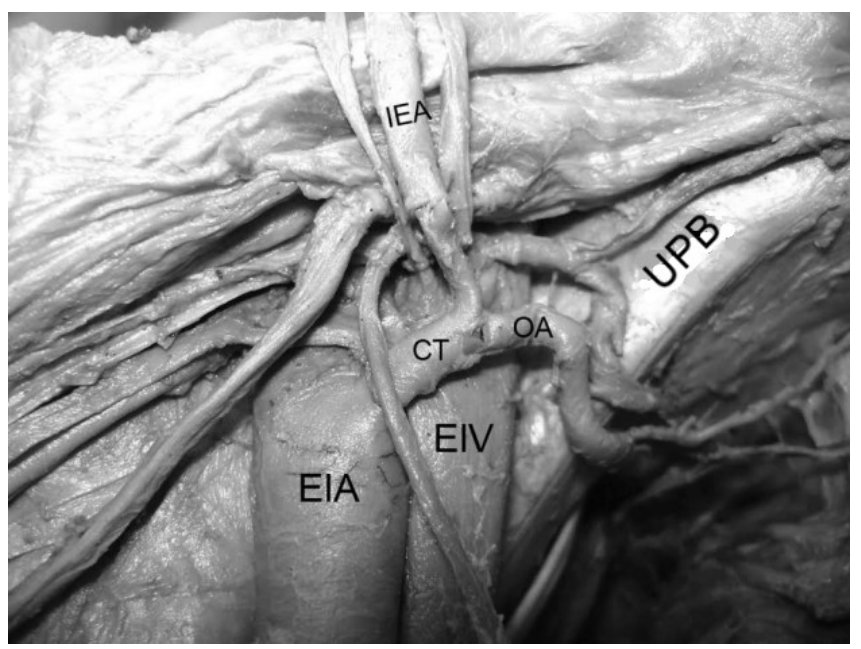

Figure 2. Dissection of a left hemipelvis. Anterior view. The common trunk between the inferior epigastric artery and the obturator artery can be seen.

External iliac artery (EIA), external iliac vein (EIV), common trunk between obturator and inferior epigastric arteries (CT), inferior epigastric artery (IEA), upper pubic branch (UPB), obturator artery (OA).

Table 1. Origins of the obturator artery.

\begin{tabular}{lcc}
\hline Origin & Number of Cases & $\%$ \\
\hline Internal Iliac Artery & 27 & $45 \%$ \\
$\begin{array}{lcc}\text { Common trunk with the } \\
\text { Inferior Epigastric Artery }\end{array}$ & 22 & $36.38 \%$ \\
Superior Gluteal Artery & 6 & $10 \%$ \\
Inferior Epigastric Artery & 4 & $6.66 \%$ \\
Femoral Artery & 1 & $1.66 \%$ \\
Total & 60 & $100 \%$ \\
\hline
\end{tabular}


Table 2. Prevalence of arterial Corona Mortis (CM).

\begin{tabular}{lccc}
\hline & Men & Women & Total \\
\hline Arterial CM & 21 & $6(22.23 \%)$ & $27(45 \%)$ \\
Absent & $(77.77 \%)$ & - & $33(55 \%)$ \\
\hline
\end{tabular}

The mean OA caliber was $2.56 \pm 0.5 \mathrm{~mm}$. The mean OA length was $57 \pm 15 \mathrm{~mm}$. The anastomotic branch had a total length of $45 \pm 4.6 \mathrm{~mm}$, a mean caliber of $2.66 \pm 0.5 \mathrm{~mm}$ and distance between the UBP and the pubic symphysis was on average $49.62 \pm 4.68 \mathrm{~mm}$. We summarize these results in table 3.

Table 3. Morphometric data of the obturator artery and its anastomotic branch.

\begin{tabular}{lcc}
\hline & $\begin{array}{c}\text { Anastomotic } \\
\text { branch } \\
(n=60)\end{array}$ & $\begin{array}{c}\text { Obturator } \\
\text { artery } \\
(n=60)\end{array}$ \\
\hline Caliber & $2.66 \pm 0.5$ & $2.567 \pm 0.5$ \\
Length & $45 \pm 4.6$ & $57.00 \pm 15$ \\
$\begin{array}{l}\text { Distance (UPB x pubic } \\
\text { symphysis) }\end{array}$ & $49.62 \pm 4.68$ & \\
\hline Restlsar dis &
\end{tabular}

Results are described as mean \pm standard deviation. UPB = upper pubic branch.

\section{DISCUSSION}

Vascular formation during the embryonic period consists of the appearance of vessels and anastomoses that may or may not persist during ontogenesis ${ }^{10}$. Two arterial plexuses are formed through the dorsal root of the umbilical artery: the abdominal plexus and the pelvic plexus. During the fifth week of development, the umbilical arteries form a new connection to the fifth pair of lumbar segmental arteries (which form the pelvic plexus), and then form the IIA, the EIA, and consequently the common iliac artery. The OA is formed through the IIA, whereas all other arteries of the lower limbs develop like branches from the EIA, for example, the IEA ${ }^{10-12}$. Due to the large number of anastomoses during this period, such arteries are susceptible to originate from neighboring vessels. Therefore, a random selection of arterial canals would explain the variability of the OA origin ${ }^{13}$. This selection would also imply differences in the caliber of the $\mathrm{OA}$ and the IEA, causing the variation known as CM. Anatomical variations of the OA origin are described in detail in the literature: it may originate from the EIA, from an ischial-pudendal trunk (formed by the internal pudendal and lower gluteal arteries), the upper or lower gluteal arteries, the internal pudendal artery, the femoral artery and from two distinct roots (one from the EIA and another from the IIA $)^{1-3,10,11}$. The OA can also originate from the IEA, ilium-lumbar artery, lower bladder artery, vaginal artery, accessory hemorrhoidal artery, external pudendal artery, accessory pudendal artery, prostatic artery, and internal pudendal artery ${ }^{1,14}$.

The IEA, on the other hand, has a varied origin in relation to its position, as it can originate as much as $6 \mathrm{~cm}$ above the inguinal ligament ${ }^{1-3}$. This vessel may originate in the femoral artery and ascend to the pelvis through the femoral ring, from the deep femoral artery, from a common trunk with the deep circumflex artery of the ilium or from the OA itself and, in addition, there was a described case where the IEA originated from two distinct roots (from the EIA and IIA) ${ }^{1,2}$. Unusual branches of the IEA may be the dorsal artery of the penis (or clitoris), the superficial epigastric artery, the deep circumflex artery of the ilium, the medial femoral circumflex artery, and the accessory external pudendal artery. The suprapubic and funicular branches may be absent ${ }^{1,3}$.

According to Testut and Latarjet ${ }^{1}$, when the OA branches from the EIA, it can reach the OF through two distinct trajectories: 1 ) it can descend vertically through the lateral wall of the femoral vein or 2) it can enter the OF obliquely and inferiorly when crossing the superior wall of the femoral vein. The authors report that the second possibility is dangerous during hernia surgeries, due to its proximity to the hernial $\operatorname{sac}^{3}$. Goss ${ }^{2}$ states that the most dangerous moment of this second trajectory is when the OA crosses the lacunar ligament. Our results showed that the OA originated along with the IEA (or from it) in $36.68 \%$ of the cases, a significant percentage. In one of the hemipelvises studied, the OA originated from the femoral artery: a fact reported only once in a study by Sañudo et al. ${ }^{11}$.

Although the anatomy books describe the usual presence of the anastomosis between the OA and IEA anastomotic branches, they do not use the term Corona 
Mortis, and few books cite its clinical and surgical importance. The term consists of two Latin words: "corona" (used in anatomy to design structures in the form of a crown or circular form), and "mortis", which comes from the term "mors", meaning death",15. It definition is intriguing because some authors believe that it is any form of anastomosis between the IEA and the OA or between the IIA and the EIA $A^{6,8,9,16,17}$, while others believe that CM is only the anastomosis of the OA and IEA anastomotic branches 5 .

Authors like Gilroy et al. ${ }^{16}$, Mahato ${ }^{18}$ and Jusoh et al. ${ }^{13}$ use terms such as "aberrant", "accessory" or "anomalous" to refer to CM. Gilroy" states that the prevalence of CM is high, and therefore should not be called by such terms. We share this opinion.

The prevalence of arterial CM (with or without venous $(\mathrm{C}$ ) has been reported in numerous studies, ranging from 12 to $65 \% 5,6,8,9,16-26$. The results of other studies are summarized in table 4 . These numbers should draw the attention of surgeons and anatomists because the number of studies reporting a prevalence greater than $20 \%$ is higher, indicating that this variation in the arterial form is not so unusual.

Tabela 4. Prevalence of corona mortis (CM) according to the literature.

\begin{tabular}{lcc}
\hline Author/Year & $\begin{array}{c}\text { Total } \\
\text { hemipelvises }\end{array}$ & $\begin{array}{c}\text { Prevalence } \\
\text { of arterial } \\
\text { CM }\end{array}$ \\
\hline Tornetta et al. (1996) & 50 & $34 \%$ \\
Teague et al. $(1996)^{20}$ & 78 & $43 \%$ \\
Gilroy et al. $(1997)^{16}$ & 105 & $38 \%$ \\
Karakurt et al. $(2002)^{5}$ & 98 & $28.5 \%$ \\
Lau and Lee $(2003)^{21}$ & 142 & $22 \%$ \\
Okcu et al. (2004) & 150 & $19 \%$ \\
Hong et al. $(2004)^{22}$ & 50 & $34 \%$ \\
Darmanis et al. $(2007)^{8}$ & 80 & $36 \%$ \\
Mahato (2009) & 50 & $22 \%$ \\
Rusu et al. $(2012)^{23}$ & 40 & $65 \%$ \\
Stavropoulou-Deli and & & \\
Anagnostopoulou & 20 & $40 \%$ \\
(2013) & & \\
Pellegrino et al. $(2014)^{9}$ & 50 & $31 \%$ \\
Ates et al. $(2015)^{17}$ & 391 & $28.4 \%$ \\
Tajra et al. $(2016)^{25}$ & 22 & $13.69 \%$ \\
Talalwah $(2016)^{26}$ & 208 & $12 \%$ \\
Present study & 60 & $45 \%$ \\
\hline
\end{tabular}

Reports of the arterial CM's length vary: $62 \mathrm{~mm}$ according to Tornetta et al. ${ }^{19}, 52 \mathrm{~mm}$ according to Hong et al. ${ }^{22}, 68 \mathrm{~mm}$ according to Darmanis et al. ${ }^{8}$ and $52.4 \mathrm{~mm}$ according to Stavropoulou-Deli and Anagnostopoulou ${ }^{24}$. The CM's caliber is has on average between $2.6 \mathrm{~mm}^{8,22}$ and $3 \mathrm{~mm}^{24}$. The present study revealed similar results, the length being $49.6 \pm 4.6 \mathrm{~mm}$, and the caliber, $2.6 \pm 0.5 \mathrm{~mm}$. The caliber should alarm surgeons and clinicians as this vessel can cause significant bleeding should it rupture.

The IEA and OA are susceptible to iatrogenic lesions during procedures due to their variable natu-

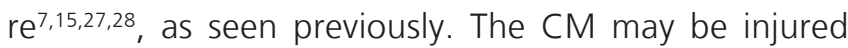
during laparoscopic approaches for repair of inguinal and femoral hernias, preperitoneal or extraperitoneal repair at the moment of attachment of the mesh to the pectineum ligament (Cooper's), which may lead to uncontrollable bleeding, pseudoaneurysms and formation of retroperitoneal hematomas ${ }^{29,30}$.

Traditional (Stoppa) accesses used for fractures of the anterior pelvic region and the anterior acetabular column are related to a high risk of hemorrhage and additional damage to adjacent structures, such as soft tissues and neurovascular structures ${ }^{27}$. The difficulty in repairing these fractures is in identifying a safe place to position the implant, especially in just-articular and quadrilateral fractures ${ }^{27}$.

In pubic osteotomies, procedures with relatively high complication rates, the CM can be injured due to a limitation of the surgical field. Since the presence of CM on the UBP posed a potential risk of injury in orthopedic surgeries, some authors suggest preoperative imaging to identify possible vascular anatomical variation to minimize complications ${ }^{31}$.

Ates et al. ${ }^{17}$ evaluated the risk of vascular injury in CM during extraperitoneal repairs and concluded that to prevent this complication careful dissection is necessary on the posterior face of UBP and to apply clips or hemostatic clamps on the pectine ligament near the pubic symphysis.

Although UBP fractures are treated with analgesics and rest, they can result in hypovolemic shock with death risk due to CM rupture. Signs of vascular injury are: palpable and painful mass in the lower abdomen, hypoperfusion, and difficulty in urinating caused 
by compression of the urinary tract by a pelvic hematoma ${ }^{32}$. An apparently benign UBP fracture associated with thermodynamics instability should raise suspicion of CM rupture, especially in elderly and anticoagulated patients. Avulsion of CM can be identified by an angiotomography ${ }^{4,15}$. Alternative treatments, such as CM embolization, may be used to stop bleeding?

Burch's colposuspension, introduced in 1961, was the gold standard for the treatment of stress urinary incontinence. Recently, this procedure has fallen into disuse due to the emergence of new minimally invasive techniques, such as the retropubic sling (introduced in 1998) or the transobturator sling (2002). These new methods, though minimally invasive, are not free of complications, since CM can still be injured ${ }^{24,33}$.

Prostatic artery embolization has shown promising results for the treatment of benign prostatic hyperplasia. The study of these vessels' anatomy should be necessary, since the prostatic artery may be an OA branch. Thus, understanding the arterial anatomy is essential for the interventional radiologist to perform the procedure safely and adequately ${ }^{14}$.
One of the interesting aspects of $C M$ is the ability to function as a collateral circulation path ${ }^{10}$. In a case described by Khandari et al. ${ }^{34}$, CM played a key role after the patient underwent avascular acetabular necrosis due to an inadequate treatment of a transverse fracture. In this situation the arterial CM participated as a collateral circulation to supply the lower limb, avoiding amputation. This aspect of CM, though extremely important, is of little emphasis in the literature.

We observed that the vascular connections between the obturator, internal and external iliac and inferior epigastric systems are relatively common over the UBP. The diameter and trajectory of this anastomotic artery may vary. latrogenic lesions and pelvic and acetabular fractures can result in severe bleeding that puts the patient's life at risk. On the other hand, this anastomosis has a considerable role as a pathway of collateral circulation in peripheral arterial obstructive disease. Thus, we note the importance of studying this anatomical variation, since we do not consider it as unusual as previously thought.

\title{
R E S U M O
}

\begin{abstract}
Objetivo: relatar a prevalência da corona mortis arterial e descrever suas aplicabilidades cirúrgicas e clínicas. Métodos: sessenta hemipelvises (50 homens e 10 mulheres) fixadas em uma solução de formalina a 10\% foram dissecadas com o propósito de obter informações sobre a corona mortis. Medidas do calibre e comprimento da artéria obturatória e seu ramo anastomótico foram mensuradas com o auxílio de um paquímetro digital e submetidas a análises e comparações estatísticas no programa GraphPad Prism 6. Resultados: a corona mortis arterial esteve presente em $45 \%$ da amostra estudada. A origem mais comum da artéria obturatória foi da artéria ilíaca interna, porém, houve um caso excepcional no qual a artéria obturatória se originou da artéria femoral. O calibre do ramo anastomótico foi em média $2.7 \mathrm{~mm}$, enquanto que o calibre da artéria obturatória foi $2.6 \mathrm{~mm}$. Conclusão: as conexões vasculares entre os sistemas obturatório, ilíacos interno e externo e epigástrico inferior são relativamente comuns sobre o ramo superior da pube. O diâmetro e a trajetória dessa artéria anastomótica podem variar. Assim, lesões iatrogênicas, fraturas pélvicas e acetabulares podem resultar em hemorragias graves que colocam a vida do paciente em risco.
\end{abstract}

Descritores: Corona Mortis. Variação Anatômica. Anatomia. Cirurgia Geral.

\section{REFERENCES}

1. Testut $L$, Latarjet $A$. Tratado de anatomía humana. Barcelona: Salvat; 1958.

2. Goss CM, editor. Gray's anatomy of the human body. Philadelphia: Lea \& Febiger; 1973.

3. Bergman R, Thompson S, Afifi A, Saadeh F. Compendium of human anatomic variation: text, atlas, and world literature. Baltimore: Urban \& Schwarzenberg; 1988.

4. Garrido-Goméz J, Pena-Rodríguez C, MartínNoguerol T, Hernández-Cortes P. Corona mortis artery avulsion due to a stable pubic ramus fracture. Orthopedics. 2012;35(1):e80-2.

5. Karakurt L, Karaca I, Yilmaz E, Burma O, Serin E. Corona mortis: incidence and location. Arch Orthop 
Trauma Surg. 2002;122(3):163-4.

6. Okcu G, Erkan S, Yercan HS, Ozic U. The incidence and location of corona mortis: a study on 75 cadavers. Acta Orthop Scand. 2004;75(1):53-5.

7. Lorenz JM, Leef JA. Embolization of postsurgical obturator artery pseudoaneurysm. Semin Intervent Radiol. 2007;24(1):68-71.

8. Darmanis S, Lewis A, Mansoor A, Bircher M. Corona mortis: an anatomical study with clinical implications in approaches to the pelvis and acetabulum. Clin Anat. 2007;20(4):433-9.

9. Pellegrino A, Damiani GR, Marco S, Ciro S, Cofelice V, Rosati F. Corona mortis exposition during laparoscopic procedure for gynecological malignancies. Updates Surg. 2014;66(1):65-8.

10. Goke K, Pires LAS, Tulio TFO, Chagas CAA. Rare origin of the obturator artery from the external iliac artery with two obturator veins. J Vasc Bras. 2016;15(3):250-3.

11. Sañudo J, Mirapeix R, Rodriguez-Niedenführ $M$, Maranillo E, Parkin IG, Vázquez T. Obturator artery revisited. Int Urogynecol J. 2011;22(10):1313-8.

12. Schoenwolf GC, Bleyl SB, Brauer PR, Francis-West $\mathrm{PH}$. Larsen's human embryology. 5th ed: Churchill Livingstone; 2014.

13. Jusoh $A R$, Rahman NA, Latiff AA, Othman F, Das $S$, Ghafar NA, et al. The anomalous origin and branches of the obturator artery with its clinical implications. Rom J Morphol Embryol 2010;51(1):163-6.

14. Garcia-Monaco R, Garategui L, Kizilevsky N, Peralta O, Rodriguez P, Palacios-Jaraquemada J. Human cadaveric specimen study of the prostatic arterial anatomy: implications for arterial embolization. J Vasc Interv Radiol. 2014;25(2):315-22.

15. Kong WM, Sun CK, Tsai IT. Delayed presentation of hypovolemic shock after a simple pubic ramus fracture. Am J Emerg Med. 2012;30(9):e2091-4.

16. Gilroy AM, Hermey DC, DiBenedetto LM, Marks SC Jr, Page DW, Lei QF. Variability of the obturator vessels. Clin Anat 1997;10(5):328-32.

17. Ates M, Kinaci E, Kose E, Soyer V, Sarici B, Cuglan S, et al. Corona mortis: in vivo anatomical knowledge and the risk of injury in totally extraperitoneal inguinal hernia repair. Hernia. 2016;20(5):659-65.

18. Mahato NK. Retro-pubic vascular anomalies: a study of abnormal obturator vessels. Eur J Anat. 2009;13(3):121-6.

19. Tornetta P 3rd, Hochwald N, Levine R. Corona mortis. Incidence and location. Clin Orthop Relat Res. 1996;(329):97-101.

20. Teague DC, Graney DO, Routt ML Jr. Retropubic vascular hazards of the ilioinguinal exposure: A cadaveric and clinical study. J Orthop Trauma. 1996;10(3):156-9.

21. Lau H, Lee F. A prospective endoscopic study of retropubic vascular anatomy in 121 patients undergoing endoscopic extraperitoneal inguinal hernioplasty. Surg Endosc. 2003;17(9):1376-9.

22. Hong HX, Pan ZJ, Chen X, Huang ZJ. An anatomical study of corona mortis and its clinical significance. Chin J Traumatol. 2004;7(3):165-9.

23. Rusu MC, Cergan R, Motoc AG, Folescu R, Pop E. Anatomical considerations on the corona mortis. Surg Radiol Anat. 2010;32(1):17-24.

24. Stavropoulou-Deli A, Anagnostopoulou S. Corona mortis: anatomical data and clinical considerations. Aust N Z J Obstet Gynaecol. 2013;53(3):283-6.

25. Tajra JBM, Lima CF, Pires FR, Sales $L$, Junqueira $D$, Mauro E. Variability of the obturator artery with its surgical implications. J Morphol Sci. 2016;33(2):968.

26. Al Talalwah W. A new concept and classification of corona mortis and its clinical significance. Chin J Traumatol. 2016;19(5):251-4.

27. Balbachevsky D, Pires RES, Faloppa F, Reis FB. Treatment of pelvic and acetabular fractures through modified Stoppa port. Acta Ortop Bras. 2006;14(4):190-2.

28. Leite TFO, Chagas CAA, Pires LAS, de Paula RC, Babinski MA. De Garengeot's hernia in an 82-yearold man: a case report and clinical significance. J Surg Case Rep. 2016;2016(7):pii: rjw120.

29. Poelman MM, van den Heuvel $B$, Deelder JD, Abis GS, Beudeker N, Bittner RR, et al. EAES Consensus Development Conference on endoscopic repair of groin hernias. Surg Endosc. 2013;27(10):3505-19.

30. Ramser $M$, Messmer AS, Zbinden I, Von Holzen $U$, Nebiker CA. Incarcerated obturator hernialaparoscopic repair with intraoperative view of the corona mortis. J Surg Case Rep. 2014;2014(8): pii: 
rju081.

31. Wada K, Goto T, Tezuka F, Tamaki S, Hamada D, Tsutsui $T$, et al. Variations in the obturator artery around the obturator foramen assessed by threedimensional computed tomographic angiography and prevention of vascular-related complications in rotational acetabular osteotomy. Int Orthop. 2016;41(1):133-9.

32. Theodorides AA, Morgan BW, Simmons D. Haemodynamic instability resulting from a low energy pubic ramus fracture in a 78-year-old woman. A case report and review of the literature. Injury. 2011;42(7):722-4.

33. Rehder P, Glodny B, Pichler R, Mitterberger MJ. Massive retropubic hematoma after minimal invasive mid-urethral sling procedure in a patient with a corona mortis. Indian J Urol. 2010;26(4):577-9.

34. Kandhari VK, Desai MM, Bava SS, Wade RN. Avascular necrosis of acetabulum: the hidden culprit of resistant deep wound infection and failed fixation of fracture acetabulum - a case report. J Orthop Case Rep. 2015;5(4):36-9.

Received in: 05/04/2017

Accepted for publication: 20/07/2017

Conflict of interest: none.

Source of funding: none.

\section{Mailing address:}

Túlio Fabiano de Oliveira Leite

E-mail: tuliofabiano@hotmail.com / lucaspires@id.uff.br 